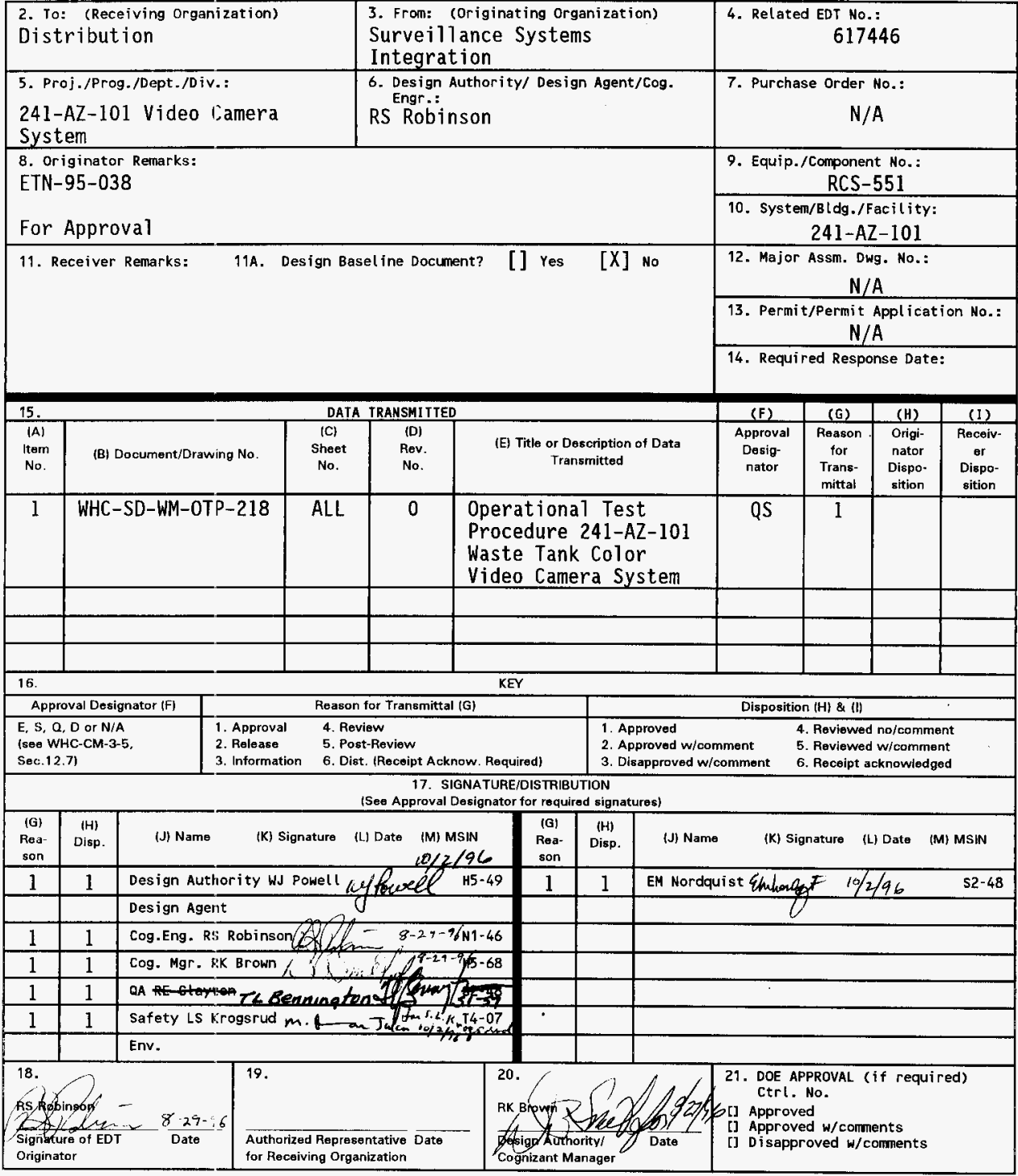

BD-7400-172-2(05/96) GEF097 


\section{OPERATIONAL TEST PROCEDURE 241-AZ-101 WASTE TANK COLOR VIDEO CAMERA SYSTEM}

\section{RS Robinson}

Westinghouse Hanford Co., Richland, WA 99352

U.S. Department of Energy Contract DE-AC06-87RL10930

EDT/ECN: 617447

Org Code: $74 F 40$

B\&R COde: 39EW 31301
UC: 720

Charge Code: BZEA1 DZDA1

Total Pages: 16

Key Words: Purge, Electrical Shutdown Control Panel, 241-AZ-101 Waste Tank Video Camera System, RCS-550, RCS 551, OTP

Abstract: The purpose of this procedure is to provide a documented means of verifying that all of the functional components of the 241-AZ101 Waste Tank Video Camera System operate properly before and after installation.

TRADEMARK DISCLAIMER. Reference herein to any specific comercial product, process, or service by trade name, trademark, manufacturer, or otherwise, does not necessarily constitute or imply $i$ ts endorsement, recommendation, or favoring by the United States Government or any agency thereof or its contractors or subcontractors.

Printed in the United States of America. To obtain copies of this document, contact: WHC/BCS Document Control Services, P.O. Box 1970, Mailstop H6-08, Richland WA 99352, Phone (509) 372-2420;
Fax (509) 376-4989.
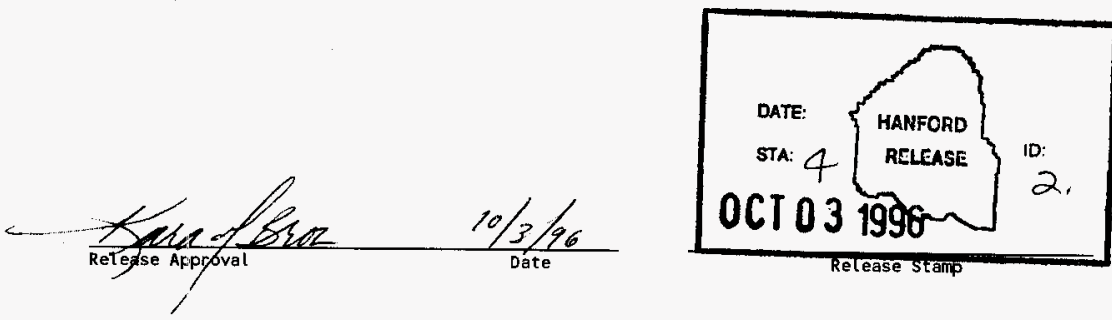

\section{Approved for Public Release}


WHC-SD-WM-OTP-218, Rev. 0

\section{OPERATIONAL TEST PROCEDURE 241-AZ-101 WASTE TANK COLOR VIDEO CAMERA SYSTEM}

Surveillance Systems Integration 


\section{WHC-SD-WM-OTP-218, Rev. 0}

TABLE OF CONTENTS

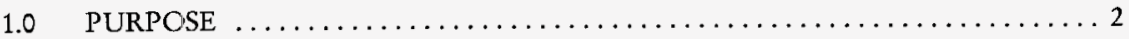

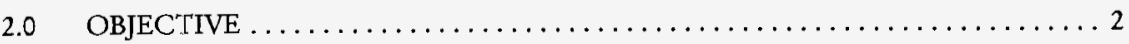

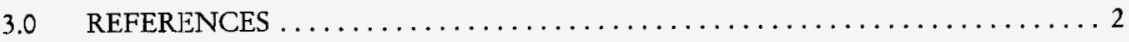

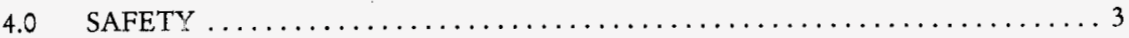

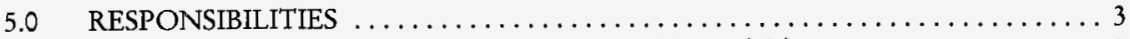

5.1 SURVEILLANCE SYSTEMS INTTEGRATION (SSI) $\ldots \ldots \ldots \ldots \ldots \ldots$

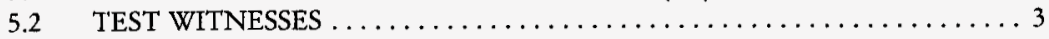

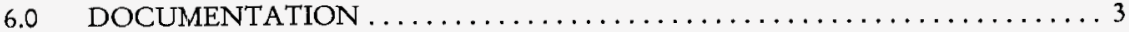

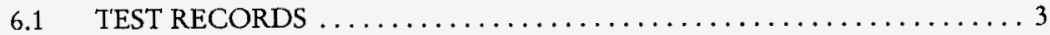

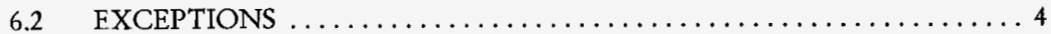

6.3 TEST EXECUTION RECORD $\ldots \ldots \ldots \ldots \ldots \ldots \ldots \ldots \ldots \ldots \ldots \ldots \ldots \ldots \ldots$

7.0 PRE-INSTALLATION OPERATIONAL TEST STEPS $\ldots \ldots \ldots \ldots \ldots \ldots \ldots \ldots$

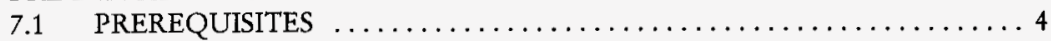

7.2 ELECTRICAL SHUTDOWN CONTROL PANEL (ESCP) $\ldots \ldots \ldots \ldots \ldots 5$

7.3 R.CS-551 CAMERA UNIT OPERABILITY $\ldots \ldots \ldots \ldots \ldots \ldots \ldots \ldots \ldots 7$

7.4 PTE-600 PAN AND TILT OPERABILITY $\ldots \ldots \ldots \ldots \ldots \ldots \ldots \ldots \ldots$

7.5 LOSS OF PURGE SHUTDOWN VERIFICATION $\ldots \ldots \ldots \ldots \ldots \ldots 9$

7.6 FINAL ACCEPTANCE $\ldots \ldots \ldots \ldots \ldots \ldots \ldots \ldots \ldots \ldots \ldots$

8.0 POST-INSTALLATION OPERATIONAL TEST STEPS .............. 10

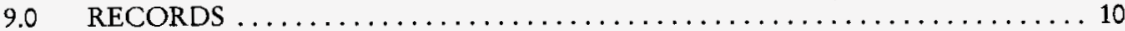

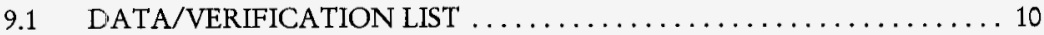

9.2 TEST EXECUTION RECORD $\ldots \ldots \ldots \ldots \ldots \ldots \ldots \ldots \ldots \ldots \ldots \ldots$

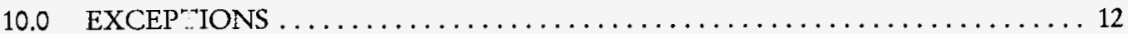

FIGURE 1. CAMERA MAST COMPONENTS $\ldots \ldots \ldots \ldots \ldots \ldots \ldots \ldots \ldots \ldots$

FIGURE 2. ELECTRICAL CONFIGURATION $\ldots \ldots \ldots \ldots \ldots \ldots \ldots \ldots \ldots \ldots \ldots \ldots$ 


\subsection{PURPOSE}

This procedure will document the satisfactory operability of the 241-AZ-101 Waste Tank Color Video Camera System. The camera assembly, including camera mast, pan-and-tilt unit, camera, and lights, will be installed in Tank 241-AZ-101 to monitor activities during the Double Shell Tank (DST) Retrieval Project. See Figure 1 for a diagram of the camera assembly.

The testing portions of this procedure are performed in two separate sections $(7.0$ and 8.0) identified below:

- Section 7.0 (Pre-Installation Operational Test) will be performed at the 200 East Area in the 241-AZ Tank Farm following installation of the master control station components, cables and local interface panel. The camera assembly will be lifted by a mobile crane in accordance with an approved installation procedure. This test will be performed while the camera assembly is suspended from the crane prior to installation into the designated riser.

- Section 8.0 (Post-Installation Operational Test) will be performed at the 200 East Frea at the 241-AZ Tank Farm following installation of the camera assembly into the designated riser in tank 241-AZ-101.

\subsection{OBJECTIVE}

The objective of this procedure is to demonstrate and document the operability of the 241-AZ-101 Waste Tank Color Video Camera System. The camera focus, iris, and zoom remote controls will be functionally tested. The pan-and-tilt unit will be tested for required ranges of motion, and the camera lights will be functionally tested. The purge function of the camera will be functionally tested to verify that ten volumes of air are exchanged during purge cycle, and that pressure and flow exists during operation of the system. Automatic electrical shutdown of system upon loss of pressure will be demonstrated.

\subsection{REFERENCES}

- Purchase Specification WHC-S-0410, Rev 1 (P.O.\#W-408171), "241-AZ-101, W151 Project, Suspended Fixture and Weld Inspection Camera System."

- WHC-SD-W151-ETP-001, Rev. 1, "Engineering Task Plan for The 241-AZ-101 Waste Tank Color Video Camera System".

- WHC-SD-WM-ATP-181, Rev. 0, "Acceptance Test Procedure 241-AZ-101 Waste Tank Color Video Camera System". 
- WHC-SD-W151-FDC-001, Rev. 3, "Functional Design Criteria (Project W-151) Tank 101-AZ Waste Retrieval System".

- WHC-SD-WM-PTP-027, Rev. 2, "Mixer Pump Process test Plan".

\subsection{SAFETY}

A pre-job meeting will be held prior to performing the OTP. Potential tripping hazards, lifting techniques and equipment safety issues will be addressed as part of the pre-job. Only the test Engineer, and/or approved personnel shall operate the camera system and related equipment.

\subsection{RESPONSIBILITIES}

\subsection{SURVEILLANCE SYSTEMS INTEGRATION (SSI)}

SSI will provide the Test Engineer. The Test Engineer will ensure that all necessary preparations for this OTP have been completed prior to beginning the test. The Test Engineer will organize and give final direction for the test aztivities. The Test Engineer may be the Cognizant Engineer, or other SSI personnel familiar with the 241-AZ-101 Waste Tank Color Video Camera System. SSI will coordinate all of the arrangements necessary to perform the OTP. An Operational Test Report (OTR) will be issued upon completion of this OTP.

\subsection{TEST WITNESSES}

DST Retrieval Projects, Operations and Quality Assurance will provide a representative to witness the satisfactory completion and approval of pertinent steps identified in this procedure. Witnesses are responsible for verifying that organizational requirements are met throughout the testing and documentation sequences of the procedure.

\subsection{DOCUMENTATION}

\subsection{TEST RECORDS}

6.1.1 All personnel involved in the performance of this test including SSI Test Engineer shall fill out a line in Section 9.0, RECORDS.

6.1.2 Test results shall be recorded by the SSI Test Engineer. All entries into this test procedure shall be made in black ink. The signature or initial of the person accepting the item will be entered in the blank provided to indicate compliance with the stated requirements or the successful 
completion of the given test step. Errors shall be corrected by crossing out the incorrect data with a single line and the correct response shall be written in the direct vicinity of the original item. The person making the correction shall initial and date the correction. Unacceptable conditions or readings shall be resolved in accordance with Section 10.0, EXCEPTIONS. A complete working copy of this procedure and any exception records generated shall be maintained as a permanent record.

\subsection{EXXCEPTIONS}

Exceptions by step number, and other notes, are to be recorded in Section 10.0. $7^{\prime}$ his section must be dispositioned (including the generation of any required $\mathrm{E}(\mathrm{CNs})$ and signed off prior to final OTP acceptance. If no exceptions are encountered, this section may be so noted and closed out with the required signatures.

\subsection{T'EST EXECUTION RECORD}

The final acceptance of the OTP results shall be indicated by signatures listed under Section 9.2, TEST EXECUTION RECORD. SSI will also issue an Operational Test Report (OTR) upon completion of this OTP.

\subsection{PRE-INSTALLATION OPERATIONAL TEST STEPS}

\subsection{PREREQUISITES}

7.1.1 The Test Engineer shall verify that all the components to the 241-AZ-101 Camera System are properly connected prior to energizing the system, (see Figures 1 and 2).

\section{Component Connections:}

$\begin{array}{ll}\text { - } & \text { Camera Control Unit } \\ \text { - } & \text { Color Mone Recorder } \\ \text { - } & \text { Electrical Shutdown Control Panel (ESCP) } \\ \text { - } & \text { Las Supply (Compressor or Farm Instrument Air) } \\ \text { - } & \text { Camera Mast Junction Box }\end{array}$

7.1.2 Verify/Ensure that the locking collar is positioned and secured properly. SSI Test Engineer Initial 
WHC-SD-WM-OTP-218, Rev. 0

7.1.3 Verify/Ensure that cables and hoses are connect to the top of the mast and have strain relief.

SSI Test Engineer Initial

7.1.4 Camera mast is to be lifted by a crane into a vertical configuration to perform operational testing.

SSI Test Engineer Initial

7.1.5 Adjust and verify that the camera is hanging in the 180 degree position (straight down) and the tilt arms are secured.

SSI Test Engineer Initial

7.1.6 Verify steps 7.1.1 through 7.1.5 are complete.

Test Engineer Date

\subsection{ELECTRICAL SHUTDOWN CONTROL PANEL (ESCP) OPERABILITY}

7.2.1 Verify ESCP unit, Serial Number 0004, has been attached to system. SSI Test Engineer Initial

7.2.2 POWER display located on the front face of the ESCP illuminates when the unit ON/OFF switch is moved to the ON position and power is available inside the box. Apply power to the unit and verify that the POWER light is functional.

SSI Test Engineer Initial

7.2.3 Turn on gas supply to allow for flow and pressure through the ESCP.

SSI Test Engineer Initial

7.2.4 START/RESET display located on the front face of the ESCP operates when flow has been sensed. Press the START/RESET button and verify that the FLOW indicator illuminates.

SSI Test Engineer Initial 
WHC-SD-WM-OTP-218, Rev. 0

7.2.5 PRESSURE \#1 and PRESSURE \#2 displays illuminate when pressure is sensed. With the START/RESET button previously activated, verify that the PRESSURE \#1 and PRESSURE \#2 indicators illuminate.

SSI Test Engineer Initial

7.2.6 PURGING display illuminates when the ESCP begins the purge cycle. After pressing the START/RESET button, verify that the PURGING indicator is illuminated.

SSI Test Engineer Initial

NOTE: The total volume of the camera mast system (mast, camera housing, light housing, pan-and-tilt, and hoses) is $1.53 \mathrm{ft}^{3}$. Per NFPA 496 requirements, ten volumes of purge air or $15.3 \mathrm{ft}^{3}$, must flow through the system. The Time Delay Relay (TDR) located in the Electrical Shutdown Control Panel (ESCP) will be adjusted to a minimum of 10.2 minutes at a minimum flow rate of $1.5 \mathrm{cfm},\left(15.3 \mathrm{ft}^{3} / 1.5 \mathrm{cfm}=10.2\right.$ minutes $)$ to allow for $15.3 \mathrm{ft}^{3}$ total flow.

7.2.7 Press the START/RESET switch located on the ESCP to begin purge cycle. With a stopwatch, time the duration of the purge cycle. Purge cycle will be complete when LOAD ENERGIZED indicator located on ESCP illuminates and power is provided to camera and lights. Verify purge cycle duration is 10.2 minutes or greater. (Time should be approximately 11.5 minutes)

SSI Test Engineer Initial

7.2.8 Once purge cycle has begun, place hand over pressure relief valve and verify that flow is present at pressure relief valve located at the light housing of the camera system. Test Engineer's signature below will verify flow is present.

SSI Test Engineer Initial

7.2.9 LOAD ENERGIZED display illuminates when the ESCP has enabled power output to the 241-AZ-101 Camera System. After the unit has completed its purge cycle, verify the LOAD ENERGIZED indicator is illuminated.

SSI Test Engineer Initial 
WHC-SD-WM-OTP-218, Rev. 0

7.2.10 SSI Test Engineer sign that steps 7.2.1 through 7.2.9 are complete.

Test Engineer Date

\subsection{FiCS-551 CAMERA UNIT OPERABILITY (Serial Number 632)}

7.3.1 Using remote camera zoom control, manipulate the zoom control to wide angle. VERIFY the zoom moves towards wide when operated towards "wide".

SSI Test Engineer Initial

7.3.2 Manipulate the zoom control to telephoto. VERIFY the zoom moves towards telephoto when operated towards "telephoto".

SSI Test Engineer Initial

7.3.3 Manipulate the iris control to fully open. VERIFY the iris moves towards open when operated.

SSI Test Engineer Initial

7.3.4 Manipulate the iris control to the fully closed position. VERIFY the iris moves towards the closed position when operated.

SSI Test Engineer Initial

7.3.5 Using the near focus control. VERIFY that the focus adjusts to near when focused on an object that is "near".

SSI Test Engineer Initial

7.3.6 Using the far focus control. VERIFY that the focus adjusts to far when focused on an object that is "far".

SSI Test Engineer Initial

7.3.7 Turn on the system lights. Verify that light $\# 1$ and $\# 2$ are functioning. SSI Test Engineer Initial 


\section{WHC-SD-WM-OTP-218, Rev. 0}

7.3.8 Using the light intensity control. Verify the light intensity can be adjusted up and down.

SSI Test Engineer Initial

7.3.9 Verify the video monitor and video recorder are operational.

SSI Test Engineer Initial

7.3.10 VERIFY steps 7.3.1 through 7.3.9 are complete.

Test Engineer

Date

7.4 F'TE-600 PAN AND TILT OPERABILITY (Serial Number 629)

7.4.1 Using the remote pan control, pan in the clockwise direction until stop is reached. Verify pan encoder reads 1 degree or less.

SSI Test Engineer Initial

7.4.2 Pan in the counterclockwise direction until stop is reached. Verify pan encoder reads 358 degrees or greater.

SSI Test Engineer Initial

7.4.3 Tilt the camera to the extreme back position. VERIFY that the camera encoder reads 270 degrees or greater and the electronic brake holds.

SSI Test Engineer Initial

7.4.4 Tilt the camera up to the extreme upward position. VERIFY that the tilt encoder reads 70 degrees or less and the electronic brake holds.

SSI Test Engineer Initial

7.4.5 Place the camera tilt in the 180 degree position for installation.

SSI Test Engineer Initial

7.4.6 VERIFY steps 7.4.1 through 7.4.5 are complete.

SSI Test Engineer

Date 
WHC-SD-WM-OTP-218, Rev. 0

\subsection{I,OSS OF PURGE SHUTDOWN VERIFICATION}

7.5.1 Manually disconnect the air supply to the camera at the input to the ESCP. Verify that system power down occurs immediately after gas flow is interrupted and that SYSTEM ENER GIZED and FLOW indicator lights located on the ESCP are no longer illuminated.

SSI Test Engineer Initial

7.5.2 Verify that the PRESSURE 1 and PRESSURE 2 indicator lights are no longer illuminated after all pressure has been bled out of the system.

SSI Test Engineer Initial

7.5.3 Reconnect the air supply to input of the ESCP unit.

SSI Test Engineer Initial

7.5.4 VERIFY steps 7.5.1 through 7.5.3 are complete.

SSI Test Engineer Date

\subsection{FINAL ACCEPTANCE}

Pre-Installation testing per this procedure is completed satisfactorily and the 241A.Z-101 Video Camera System is ready for installation.

SSI Test Engineer: Date

Operations: Date

Quality Representative: Date

DST Retrieval Projects: Date 
WHC-SD-WM-OTP-218, Rev. 0

\subsection{POST-INSTALLATION OPERATIONAL TEST STEPS}

Repeat sections 7.2 (Step 7.2.8 shall not be performed), 7.3 and 7.4 of this procedure to ensure that the 241-AZ-101 Video Camera System is operating satisfactorily after installation of the camera assembly into the designated riser.

SSI Test Engineer:

Date

Operations:

Date

Quality Representative:

Date

DST Recrieval Projects:

Date

\subsection{RECOKDS}

\subsection{DATA/VERIFICATION LIST}

\begin{tabular}{|c|c|c|c|c|}
\hline $\begin{array}{l}\text { NAME } \\
\text { PRIN }^{-n}\end{array}$ & $\begin{array}{l}\text { NAME } \\
\text { SIGN }\end{array}$ & INITIALS & POSITION & DATE \\
\hline & & & & \\
\hline & & & & \\
\hline & & & & \\
\hline & & & & \\
\hline & & & & \\
\hline & & & & \\
\hline & & & & \\
\hline & & & & \\
\hline
\end{tabular}




\section{WHC-SD-WM-OTP-218, Rev. 0}

9.2 TEST EXECUTION RECORD

Signatures below indicate concurrence with the following:

- The objectives delineated in Section 2.0 of this procedure have been achieved

- All recorded exceptions have been resolved, the resolutions approved and any necessary retesting completed

- The 241-AZ-101 Video Camera System is ready for service.

SSI Test Engineer:

Date

Operations:

Date

Quality Representative:

Date

DST Retrieval Projects:

Date 
WHC-SD-WM-OTP-218, Rev. 0

\subsection{EXCEPTIONS}

EXCEPTION SHEET NUMBER:

PROCEDURE STEP:

Note: Make additional copies of this page as necessary.

Description of Problem:

Exception Resolution:

SSI Test Engineer:

Date

Operations:

Date

Quality Representative:

Date

DST Retrieval P'rojects:

Date 


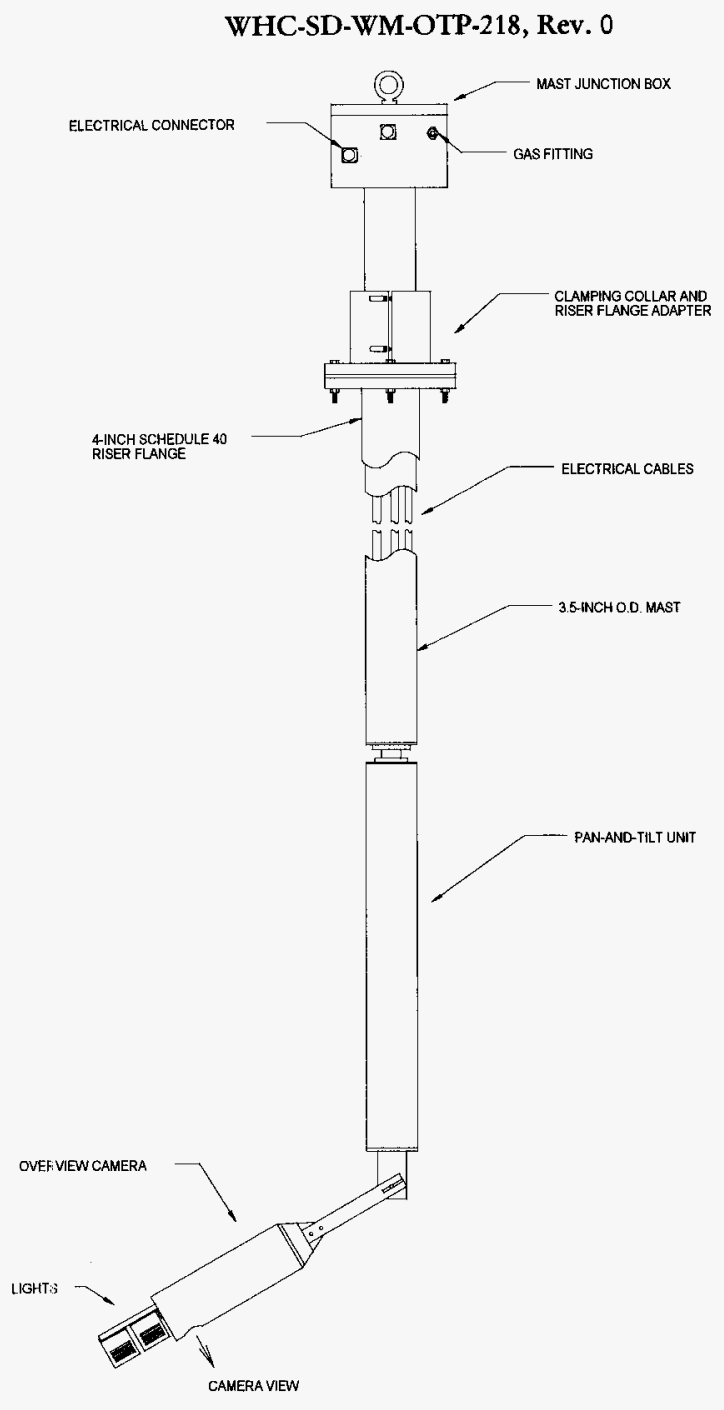

FIGURE 1. CAMERA MAST COMPONENTS 
WHC-SD-WM-OTP-218, Rev. 0

\section{1-AZ-101 CONNECTION DETAIL}

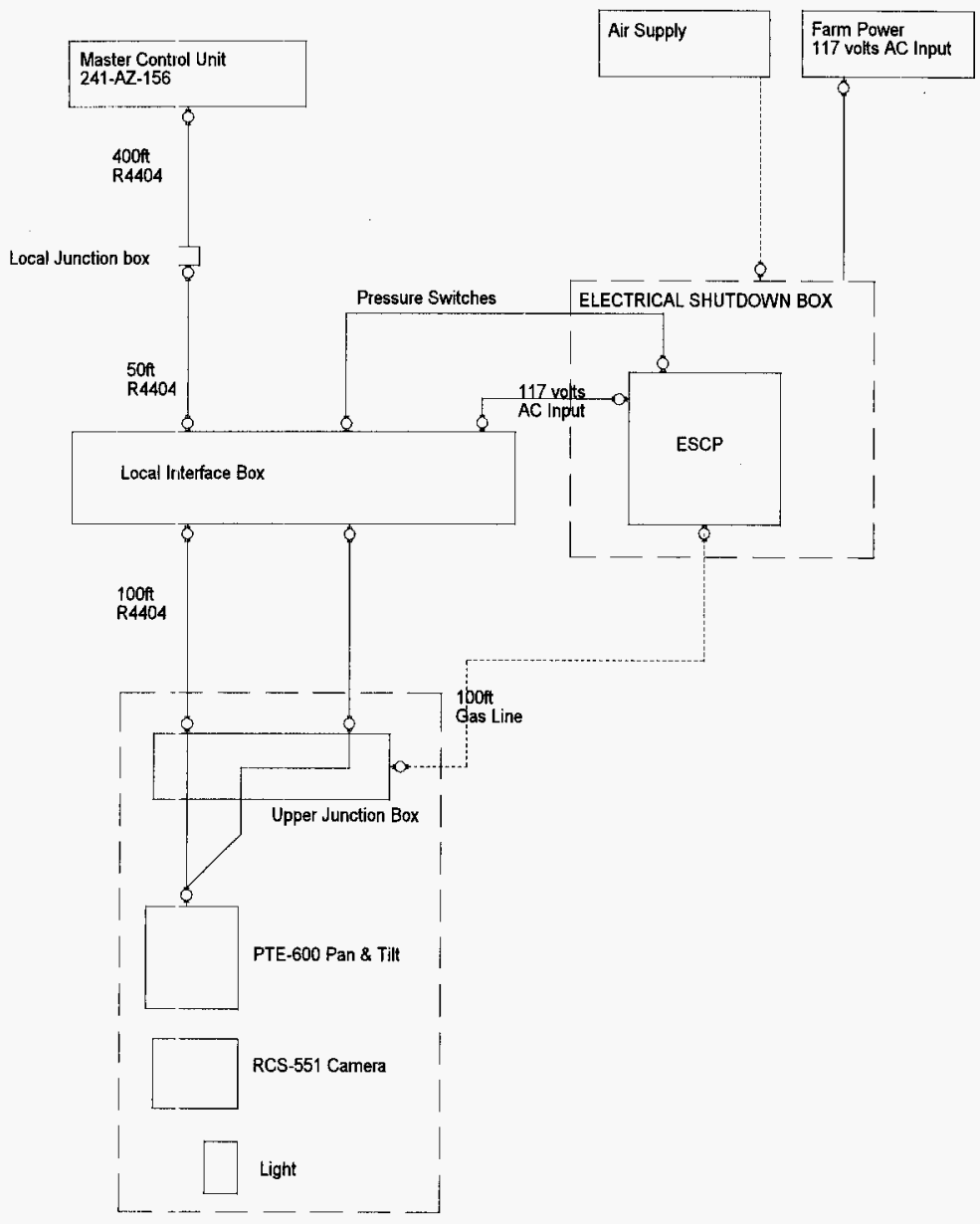

CAMERA MAST

FIGURE 2. ELECTRICAL CONFIGURATION 


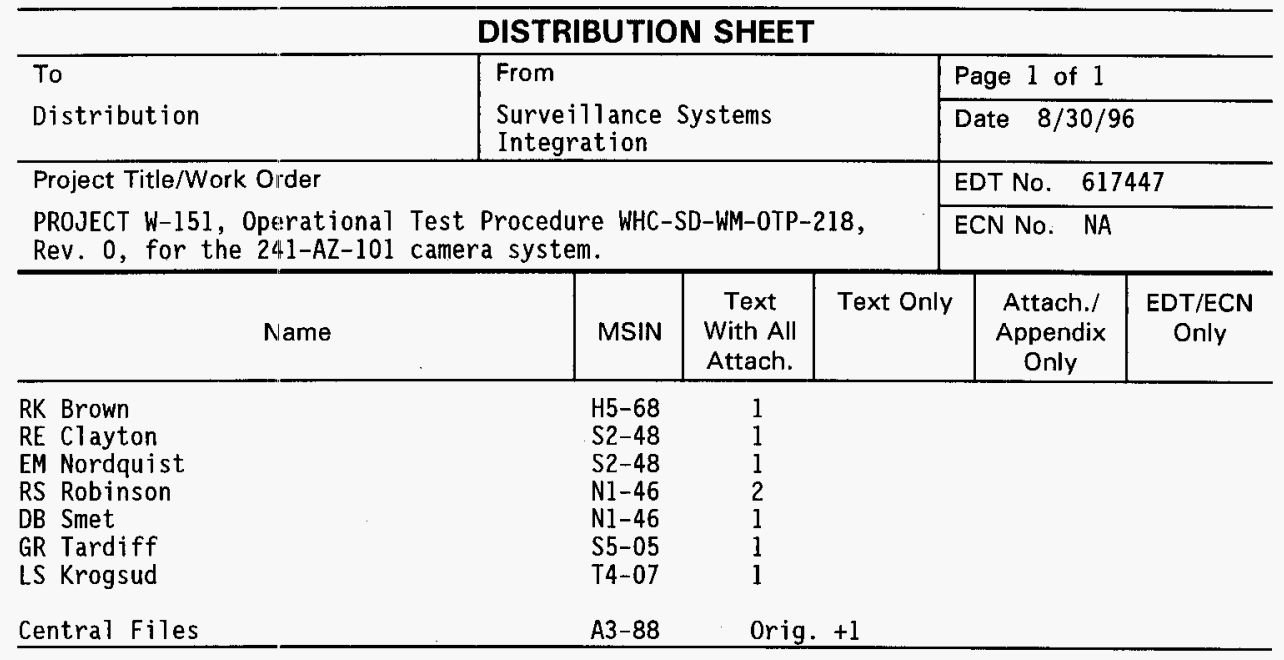

